\title{
Effect of precipitation on the acidification of soils of West Pomeranian Voivodeship
}

\author{
Piotr Daniszewski ${ }^{1 *}$, Beata Draszawka - Bołzan ${ }^{2}$ \\ ${ }^{1}$ Department of Invertebrate Zoology and Limnology, University of Szczecin, \\ 13 Waska Street, 71-415 Szczecin, Poland \\ ${ }^{2}$ Department of Chemistry and Protection of the Aquatic Environment, University of Szczecin, \\ 3C Felczaka Street, 71-412 Szczecin, Poland \\ *E-mail address: daniszewski@univ.szczecin.pl
}

\begin{abstract}
The progress of civilization as well as the growing up process of transformative environment adversely affect individual environmental elements in the soil. In recent years the increasing pollution of the atmosphere causes more and more interest in the science of the substances contained in it and merge back to the surface of the Earth. Of great importance for the environment have the substances contained in the water drainage, as in the form of dissolved very easily reach the individual environmental elements causing their contamination. Strong acidification most soils in Poland is the main cause of weak download main nutrients in soils, and low yields. Part of important plant micronutrients: iron, copper, zinc, manganese, cobalt/an acidic soils are more available In soils acidic phosphorus being introduced in mineral fertilisers is associated with aluminum and iron, in forms not available for plants. The low $\mathrm{pH}$ of the soil inhibits the oxidation of ammonium nitrogen $\left(\mathrm{NH}_{4}^{+}\right)$to nitrate $\left(\mathrm{NO}_{3}{ }^{-}\right)$, and at the same time, poorly developed root system is not able to efficiently download ion nitrate from the soil. The result is outside the range of the washing of nitrate nitrogen contamination of groundwater and is followed by the root system. The purpose of the work was to determine the $\mathrm{pH}$ of precipitation and atmospheric.
\end{abstract}

Keywords: wet the fallout of atmospheric pollutants; $\mathrm{pH}$; concentration of chemical components; soil

\section{INTRODUCTION}

The progress of civilization as well as the growing up process of transformative environment adversely affect individual environmental elements in the soil [1-3, 5-10, 25-28, 49]. These processes they realize that individual elements of environmental protection becomes the basis for the further development of socio-economic $[1,2,4,6,7,9,11-13$, 1921]. In recent years the increasing pollution of the atmosphere causes more and more interest in the science of the substances contained in it and merge back to the surface of the Earth [1, $3,4,14,15,17,18,24-28]$.

Of great importance for the environment have the substances contained in the water drainage, as in the form of dissolved very easily reach the individual environmental elements causing their contamination [1, 3, 4, 19-21, $24-28,46,49]$.

The change of the reaction of the soil be subject are among others. the influence of the progress of civilization $[1,2,5,7,8,11,12,14,16,18,19,49]$. External source of 
acidification of soils are mainly fertilizers (ammonium and amide) and acid rain [17-20, 22, $27,28,30-32,35,37,39]$.

In soils, the immediate source of hydrogen's main cultivated cation $\left(\mathrm{H}^{+}\right)$is carbon dioxide (CO2), that by dissolving in water forms carbonic acid. This acid then breaks down releasing the ion $\mathrm{H}^{+}$. Carbon dioxide $(\mathrm{CO} 2)$ is produced from the decomposition of organic matter in soils and in the process of breathing roots [27, 30, 32, 38, 41-46, 48].

In the intensive agriculture of the $\mathrm{CO} 2$ production is significant, leading to increased acidification of soils. Second, a very important source of $\mathrm{H}^{+}$ions is the oxidation of ammonium nitrogen in soil, put it in organic fertilisers and scrap crop residues, and also in the mineral nitrogen fertilisers. Part of the ammoniacal nitrogen in the process of nitrification in the form of nitrogen and transformed into are released free $\mathrm{H}^{+}$ions [27, 29, 32, 38, 41-48].

Another source of acidification of soils are the $\mathrm{H}+$ ions released during weathering in soils of compounds of iron, manganese and sulfur. This is a significant factor, because for about $90 \%$ of soils in Poland produced is the acidic rocks. They are followed by Alkaline Elution on intensive nutrients (calcium, magnesium and potassium) [27, 29, 32, 38, 41-47].

These elements are also exported from fields, from crop, which contributes to the acidification of soils $[27,29,32,38,41-46,48]$. The $\mathrm{pH}$ of the soil determines its life and of nutrient nitrogen fractions, both macro and micro nutrients [28, 30, 32, 34, 36, 38, 41-46, 48].

On soils very strongly with $\mathrm{pH}$ 4/an acidic-nitrogen, phosphorus, potassium, calcium, magnesium are very poorly available to plants.

The bioavailability of their increases as $\mathrm{pH}$. It is worth noting that in the conditions of low $\mathrm{pH}$ the least of macro-elements available to plants is-magnesium. This explains the absolute necessity of fertilizing with lime and magnesium/an acidic soils and at the same time, the poor in magnesium [32, 34-36, 38, 41-46, 48]. Strong acidification most soils in Poland is the main cause of weak download main nutrients in the soils, and the same low yields [27, 29, $32,38,41-46,48]$.

Part of important plant micronutrients: iron, copper, zinc, manganese, cobalt are more available on/an acidic [27, 29, 30, 32, 38, 41-46, 48]. In soils acidic phosphorus being introduced in mineral fertilisers is associated with aluminum and iron, in forms not available for plants $[27,29,32-34,36,37,41-46,48]$. The low $\mathrm{pH}$ of the soil inhibits the oxidation of ammonium nitrogen $\left(\mathrm{NH}_{4}{ }^{+}\right)$to nitrate $\left(\mathrm{NO}_{3}{ }^{-}\right)$, and at the same time, poorly developed root system is not able to efficiently download ion nitrate from the soil. The result is outside the range of the washing of nitrate nitrogen contamination of groundwater and root system following [27-29, 32, 38, 40-45, 47, 48].

The purpose of the work was to determine the $\mathrm{pH}$ of precipitation and atmospheric.

\section{PART OF THE EXPERIMENTAL}

Research was carried out in the years 2008-2011 (January-December) in the city of Szczecin and Międzyzdroje. Szczecin is situated in North-Western Poland, in the western part of the province. West at the Polish-German border. The town lies on the river Oder and the Lake Dąbie, covering part of the inter-Odra [23-26]. Szczecin is located on the city's Lower Oder Valley four geographical: Szczecin, Beech Hill, Elevation and Plain Goleniowska - they are part of port of Szczecin [23-26].

The most affecting the North Atlantic air mass polar marine from the high humidity, which affects the increase in cloud cover and in the summer the amount of precipitation; in winter involves a warming and a large and. These weight most outstanding summer and autumn [23-26]. 
Less likely to flood the air polar marine from Eastern Europe and from Asia. The presence of this air is observed most commonly in winter and spring. Is it a little water vapour content [23-26]. Much less likely to flood the air Arctic-weather very variable, it brings with it major changes in temperature and spring frosts [23-26]. Least likely has the presence of air, which brings periods of rapid warming marshes, appearing sometimes in winter and occasionally in the summer [23-26]. On a map No 1 shows the location of the measuring point in the city of Szczecin.

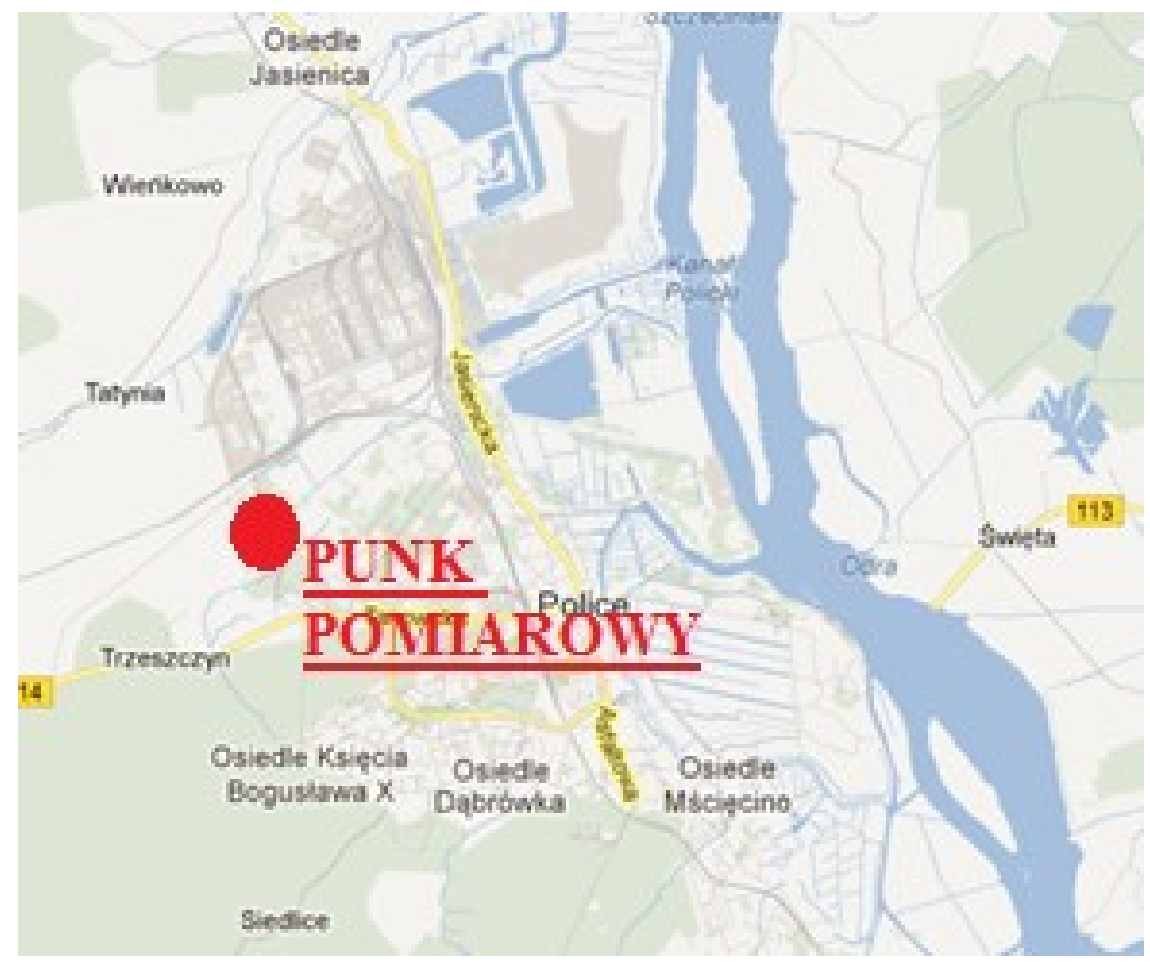

Map 1. Location of the measuring point in Szczecin. Source: Google maps 2012/Develop your own

Międzyzdroje is a city located in the north-western part of the county on the island of Wolin on the Baltic Sea [23-26].

The city is located on the Bay of Pomorska, in the central part of the coast of the island of Wolin. Part of the East of Międzyzdroje is situated on the western slopes of the remains of the Beautiful [23-26].

The climate of the island of Wolin is different from the rest of the country because the climate is strongly influenced by the presence of the Baltic Sea.

It is characterized by high humidity, sunlight and precipitation variability, wind direction and force large diurnal temperature amplitude. Międzyzdroje is a resort and tourist destination [23-26].

On a map No 2 shows the location of the measuring point in the town of Międzyzdroje. 


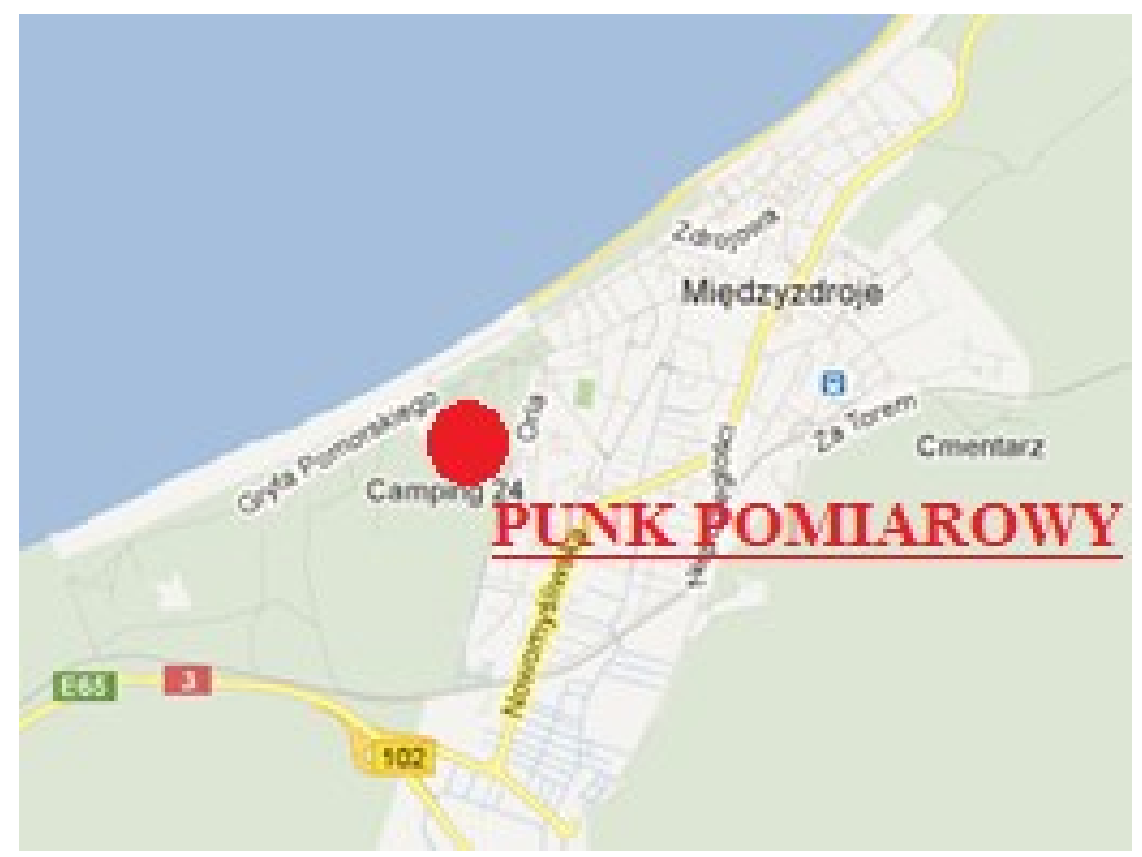

Map 2. Location of the measuring point in Międzyzdroje. Source: Google maps 2012/Develop your own

The location of the measurement points, choosing the kind of hooks precipitation and how sampling water drainage was guided by the guidelines contained in the Standard PN91C-04642/02 [50].

Sample of precipitation collectors were collected as the fallout of the total and the fallout wet. Sample was collected in the diurnal cycle. The size of the atmospheric precipitation was measured using the measurement of rain method Hellmanna (this is a measurement of rain to measure precipitation-rain and snow.

The system maintains the diurnal sampling recognized. Methodology carried out chemical indications are based on the development and others Hermanowicz [1999].

\section{DISCUSSION OF THE RESULTS}

Size distribution of precipitation in the city of Szczecin and Międzyzdroje and average monthly and annual values of $\mathrm{pH}$ are shown in tables 1-8.

Annual average $\mathrm{pH}$ value of collected rainwater in the period from 2008 to 2011, in the city of Szczecin, indicate their acidic nature (tab. 1-4). All taken for tests to try to lower the $\mathrm{pH}$ value of precipitation, wet had 5,6 which is of the value corresponding to the damage a rainwater [36].

Annual average $\mathrm{pH}$ value of collected rainwater in the period from 2008 to 2011, in the town of Międzyzdroje indicate on their acidic nature (tab. 5-8). Almost $90 \%$ of downloaded trials of the $\mathrm{pH}$ value was lower than 5,6 which is the value corresponding to the damage a rainwater [36]. 
Table 1. Mean monthly and annual precipitation (in $\mathrm{mm}$ ) and physico-chemical parameters of precipitation in 2008 [Szczecin]

\begin{tabular}{|c|c|c|c|}
\hline \multirow{2}{*}{ Month } & \multicolumn{2}{|c|}{ Upward } & \multirow{2}{*}{ pH } \\
\hline & $\mathrm{mm}$ & days & \\
\hline January & 36,2 & 19 & 4,78 \\
\hline February & 27,5 & 16 & 4,85 \\
\hline March & 34,8 & 22 & 4,89 \\
\hline April & 38,7 & 15 & 5,11 \\
\hline May & 46,3 & 10 & 5,18 \\
\hline June & 57,2 & 15 & 5,45 \\
\hline July & 70,4 & 14 & 5,68 \\
\hline August & 65,8 & 15 & 5,72 \\
\hline September & 45,9 & 17 & 5,63 \\
\hline October & 47,2 & 19 & 5,34 \\
\hline November & 43,8 & 16 & 5,08 \\
\hline December & 45,7 & 17 & 4,67 \\
\hline \multicolumn{3}{|c|}{ The average } & 5,19 \\
\hline Together 2008 & 559,5 & 195 & - \\
\hline
\end{tabular}

Table 2. Mean monthly and annual precipitation (in $\mathrm{mm}$ ) and physico-chemical parameters of precipitation in 2009 [Szczecin]

\begin{tabular}{|c|c|c|c|}
\hline \multirow{2}{*}{ Month } & \multicolumn{2}{|c|}{ Upward } & \multirow{2}{*}{ pH } \\
\cline { 2 - 3 } & $\mathrm{mm}$ & days & \\
\hline January & 38,1 & 19 & 4,62 \\
\hline February & 29,4 & 16 & 4,74 \\
\hline March & 31,7 & 22 & 4,83 \\
\hline April & 43,5 & 15 & 5,18 \\
\hline May & 52,8 & 8 & 5,23 \\
\hline June & 56,2 & 16 & 5,38 \\
\hline July & 74,1 & 14 & 5,64 \\
\hline August & 63,8 & 16 & 5,70 \\
\hline September & 43,7 & 17 & 5,67 \\
\hline October & 45,2 & 15 & 5,42 \\
\hline November & 49,5 & 17 & 5,16 \\
\hline December & 40,7 & 17 & 4,63 \\
\hline \multicolumn{2}{|c|}{ The average } & $\mathbf{5 , 1 8}$ \\
\hline Together 2009 & $\mathbf{5 6 8 , 7}$ & $\mathbf{1 9 2}$ & - \\
\hline
\end{tabular}


Table 3. Mean monthly and annual precipitation (in $\mathrm{mm}$ ) and physico-chemical parameters of precipitation in 2010 [Szczecin]

\begin{tabular}{|c|c|c|c|}
\hline \multirow{2}{*}{ Month } & \multicolumn{2}{|c|}{ Upward } & \multirow{2}{*}{ pH } \\
\cline { 2 - 3 } & $\mathrm{mm}$ & days & \\
\hline January & 34,5 & 19 & 4,73 \\
\hline February & 28,6 & 16 & 4,86 \\
\hline March & 36,9 & 21 & 4,82 \\
\hline April & 46,2 & 16 & 5,08 \\
\hline May & 53,7 & 9 & 5,24 \\
\hline June & 58,1 & 14 & 5,39 \\
\hline July & 75,9 & 13 & 5,58 \\
\hline August & 68,3 & 16 & 5,69 \\
\hline September & 45,8 & 17 & 5,70 \\
\hline October & 43,1 & 18 & 5,36 \\
\hline November & 47,6 & 16 & 5,14 \\
\hline December & 40,8 & 17 & 4,65 \\
\hline \multicolumn{2}{|c|}{ The average } & $\mathbf{5 , 1 9}$ \\
\hline Together 2010 & $\mathbf{5 7 9 , 5}$ & $\mathbf{1 9 2}$ & - \\
\hline
\end{tabular}

Table 4. Mean monthly and annual precipitation (in $\mathrm{mm}$ ) and physico-chemical parameters of precipitation in 2011 [Szczecin]

\begin{tabular}{|c|c|c|c|}
\hline \multirow{2}{*}{ Month } & \multicolumn{2}{|c|}{ Upward } & \multirow{2}{*}{ pH } \\
\cline { 2 - 3 } & $\mathrm{mm}$ & days & \\
\hline January & 35,8 & 19 & 4,78 \\
\hline February & 28,4 & 17 & 4,85 \\
\hline March & 33,7 & 22 & 4,89 \\
\hline April & 37,4 & 13 & 5,11 \\
\hline May & 43,9 & 8 & 5,18 \\
\hline June & 55,2 & 15 & 5,45 \\
\hline July & 72,4 & 17 & 5,68 \\
\hline August & 64,8 & 15 & 5,72 \\
\hline September & 44,9 & 17 & 5,63 \\
\hline October & 43,5 & 16 & 5,34 \\
\hline November & 42,7 & 18 & 5,08 \\
\hline December & 41,4 & 16 & 4,67 \\
\hline \multicolumn{2}{|c|}{ The average } & $\mathbf{5 , 2 0}$ \\
\hline Together 2011 & $\mathbf{5 4 4 , 1}$ & $\mathbf{1 9 3}$ & - \\
\hline
\end{tabular}


Table 5. Mean monthly and annual precipitation (in $\mathrm{mm}$ ) and physico-chemical parameters of precipitation in 2008 [Międzyzdroje]

\begin{tabular}{|c|c|c|c|}
\hline \multirow{2}{*}{ Month } & \multicolumn{2}{|c|}{ Upward } & \multirow{2}{*}{ pH } \\
\cline { 2 - 3 } & $\mathrm{mm}$ & days & \\
\hline January & 37,8 & 23 & 4,82 \\
\hline February & 32,3 & 17 & 4,85 \\
\hline March & 39,7 & 25 & 5,17 \\
\hline April & 42,9 & 15 & 5,24 \\
\hline May & 49,3 & 7 & 5,26 \\
\hline June & 58,2 & 13 & 5,32 \\
\hline July & 75,9 & 11 & 5,36 \\
\hline August & 68,3 & 12 & 5,41 \\
\hline September & 50,3 & 19 & 5,52 \\
\hline October & 56,3 & 15 & 5,37 \\
\hline November & 45,8 & 17 & 5,28 \\
\hline December & 48,1 & 16 & 4,92 \\
\hline \multicolumn{2}{|c|}{ The average } & $\mathbf{5 , 2 1}$ \\
\hline Together 2008 & $\mathbf{6 0 4 , 9}$ & $\mathbf{1 9 0}$ & - \\
\hline \multicolumn{3}{|c|}{}
\end{tabular}

Table 6. Mean monthly and annual precipitation (in $\mathrm{mm}$ ) and physico-chemical parameters of precipitation in 2009 [Międzyzdroje]

\begin{tabular}{|c|c|c|c|}
\hline \multirow{2}{*}{ Month } & \multicolumn{2}{|c|}{ Upward } & \multirow{2}{*}{ pH } \\
\cline { 2 - 3 } & $\mathrm{mm}$ & days & \\
\hline January & 38,3 & 24 & 4,91 \\
\hline February & 34,1 & 18 & 4,86 \\
\hline March & 37,8 & 26 & 5,21 \\
\hline April & 43,1 & 16 & 5,19 \\
\hline May & 47,4 & 10 & 5,26 \\
\hline June & 58,2 & 13 & 5,38 \\
\hline July & 65,7 & 12 & 5,41 \\
\hline August & 60,8 & 11 & 5,58 \\
\hline September & 52,6 & 18 & 5,63 \\
\hline October & 53,7 & 15 & 5,50 \\
\hline November & 47,2 & 16 & 5,46 \\
\hline December & 49,1 & 17 & 5,08 \\
\hline \multicolumn{2}{|c|}{ The average } & $\mathbf{5 , 2 9}$ \\
\hline Together 2009 & $\mathbf{5 8 8 , 0}$ & $\mathbf{1 9 6}$ & - \\
\hline \multicolumn{3}{|c}{} \\
\hline
\end{tabular}


Table 7. Mean monthly and annual precipitation (in $\mathrm{mm}$ ) and physico-chemical parameters of precipitation in 2010 [Międzyzdroje]

\begin{tabular}{|c|c|c|c|}
\hline \multirow{2}{*}{ Month } & \multicolumn{2}{|c|}{ Upward } & \multirow{2}{*}{ pH } \\
\cline { 2 - 3 } & $\mathrm{mm}$ & days & \\
\hline January & 40,8 & 24 & 4,92 \\
\hline February & 34,6 & 17 & 5,11 \\
\hline March & 38,5 & 25 & 5,17 \\
\hline April & 45,1 & 16 & 5,27 \\
\hline May & 50,7 & 8 & 5,31 \\
\hline June & 53,8 & 12 & 5,40 \\
\hline July & 80,2 & 12 & 5,53 \\
\hline August & 75,3 & 15 & 5,62 \\
\hline September & 42,8 & 17 & 5,68 \\
\hline October & 52,6 & 16 & 5,40 \\
\hline November & 47,2 & 16 & 5,51 \\
\hline December & 45,9 & 17 & 5,24 \\
\hline \multicolumn{2}{|c|}{ The average } & $\mathbf{5 , 3 5}$ \\
\hline Together 2010 & $\mathbf{6 0 7 , 5}$ & $\mathbf{1 9 5}$ & - \\
\hline \multicolumn{2}{|c}{}
\end{tabular}

Table 8. Mean monthly and annual precipitation (in $\mathrm{mm}$ ) and physico-chemical parameters of precipitation in 2011 [Międzyzdroje]

\begin{tabular}{|c|c|c|c|}
\hline \multirow{2}{*}{ Month } & \multicolumn{2}{|c|}{ Upward } & \multirow{2}{*}{ pH } \\
\cline { 2 - 3 } & $\mathrm{mm}$ & days & \\
\hline January & 45,3 & 22 & 4,89 \\
\hline February & 34,8 & 17 & 5,01 \\
\hline March & 38,4 & 25 & 5,21 \\
\hline April & 39,6 & 17 & 5,26 \\
\hline May & 47,4 & 9 & 5,57 \\
\hline June & 61,6 & 11 & 5,60 \\
\hline July & 78,5 & 14 & 5,62 \\
\hline August & 65,9 & 13 & 5,60 \\
\hline September & 45,2 & 17 & 5,54 \\
\hline October & 49,7 & 16 & 5,42 \\
\hline November & 47.3 & 17 & 5,17 \\
\hline December & 52,6 & 15 & 5,09 \\
\hline \multicolumn{3}{|c|}{ The average } & $\mathbf{5 , 3 3}$ \\
\hline Together 2011 & $\mathbf{6 0 6 , 3}$ & $\mathbf{1 9 3}$ & - \\
\hline \multicolumn{3}{|c|}{}
\end{tabular}


Annual average $\mathrm{pH}$ value of collected rainwater in the period from 2008 to 2011, in the city of Szczecin, indicate their acidic nature (tab. 1-4). All taken for tests to try to lower the $\mathrm{pH}$ value of precipitation, wet had 5,6 which is of the value corresponding to the damage a rainwater [36]. Annual average $\mathrm{pH}$ value of collected rainwater in the period from 2008 to 2011, in the town of Międzyzdroje indicate on their acidic nature (tab. 5-8). Almost $90 \%$ of downloaded trials of the $\mathrm{pH}$ value was lower than 5,6 which is the value corresponding to the damage a rainwater [36].

Source of pollution of atmospheric air in the city of Szczecin is the emission of substances from the combustion of solid fuels, liquid and gas in boiler industrial and services and road communication. An important source of pollution is also called. low-emission from coal-fired heating furnaces of boiler and home local, in which coal burning is done in the most inefficient way coal cheap, which has low heating parameters [39, 40].

Source of pollution of atmospheric air in the town of Międzyzdroje is the emission of substances from the combustion of solid fuels, liquid and gas in industrial boiler and service facilities and road communication. An important source of pollution is also called. lowemission from coal-fired heating furnaces of boiler and home local, in which coal burning is done in the most inefficient way coal cheap, which has low heating parameters.

On the status of air quality in Międzyzdroje are also affected by pollution from the directions of bank flows North-West, mainly from the port area are moving air mass in Świnoujście. The primary function of the port of Świnoujście is the transshipment of cereals, ores, oil, paper, cellulose, general cargo, coal, iron [39, 40].

\section{CONCLUSIONS}

1. Annual average $\mathrm{pH}$ value of collected rainwater in the period from 2008 to 2011, in the city of Szczecin indicated on their acidic nature.

2. The $\mathrm{pH}$ of all the samples taken, precipitation was lower than 5.6, which is wet from the values corresponding to the damage a rainwater.

3. Almost $90 \%$ of the collected samples of Birmingham had the $\mathrm{pH}$ lower than 5.6-IE. the value corresponding to the damage a rainwater.

4. Strong acidification most soils in Poland is the main cause of weak download main nutrients in soils, and low yields.

\section{POLISH STANDARD}

PN/C-04632.03. General rules for sampling for the study of the physical, chemical and biological. Sampling technique.

PN/C-04632.04. General rules for sampling for the study of the physical, chemical and biological. Recording and storage of samples.

PN/C-06504. The preparation of buffer solutions.

PN-90/C-04540/01 - determination of $\mathrm{pH}$. 


\section{REFERENCES}

[1] Binkley D., Högberg P., For. Ecol. Management, 92 (1997) 119-152.

[2] Block J., Eichborn J., Gehrmann J., Kölling C., Matzner E., Meiwes K. J. V.,Wilpert K., Wolff B., Arbeitskreis C der Bund-Länder Arbeitsgruppe Level II. BML, Bonn 2000, $1-167$

[3] Borecka-Jamro D., Szponar-Krok E., Frag. Agron. 19, 2 (74) (2002) 52-58.

[4] Cronan C. S., Aiken G. R. Geochimica and Cosmochimica Acta, New York, 49 (1985) 1697-1705.

[5] Cronan C. S., Grigal D. F., J. Environ. Qual. 24 (1995) 209-226.

[6] Cyraniak E., Daniszewski P., Draszawka - Bołzan B., International Letters of Chemistry, Physics and Astronomy 5 (2012) 88-95.

[7] Cyraniak E., Daniszewski P., Draszawka - Bołzan B., International Letters of Chemistry, Physics and Astronomy 5 (2012) 96-103.

[8] Daniszewski P., Ekologia i Technika 5 (2008) 211-214.

[9] Daniszewski P., Wiadomości Melioracyjne i Lakarskie 4 (2008) 187-188.

[11] Daniszewski P., Inżynier budownictwa nr 11/2009, s. 81-82.

[12] Daniszewski P., Gaz, Woda i Technika Sanitarna 4 (2009) 34-36.

[13] Daniszewski P., International Letters of Chemistry, Physics and Astronomy 1 (2012) 6-12.

[14] Daniszewski P., International Letters of Chemistry, Physics and Astronomy 1 (2012) 13-16.

[15] Daniszewski P., International Letters of Chemistry, Physics and Astronomy 2 (2012) $42-45$

[16] Daniszewski P., International Letters of Chemistry, Physics and Astronomy 1 (2012) 13-16.

[17] Daniszewski P., International Letters of Chemistry, Physics and Astronomy 2 (2012) $42-45$

[18] Daniszewski P., International Letters of Chemistry, Physics and Astronomy 5 (2012) $72-79$

[19] Daniszewski P., International Letters of Chemistry, Physics and Astronomy 5 (2012) 80-87

[20] Filipek J., Kasperczyk M., Skrijka P., Acta Agr. Silv. Ser. Agr. 18 (1978) 17-31.

[21] Filipek T. Nawozy i Nawozenie - Fertilizers and Fertilization, 2(23) (2005) 67-83.

[22] Filipiak K., Krakowiak A., Pietruch Cz. Państwowa Inspekcja Ochrony Środowiska, Bibliot. Monit. Środ., Warszawa 1995, ss. 41.

[23] Encyklopedia Szczecina. T. I A-O. Szczecin: Uniwersytet Szczeciński, 1999.

[24] Encyklopedia Szczecina. T. II P-Ż. Szczecin: Uniwersytet Szczeciński, 2000. 
[25] Encyklopedia Szczecina. T. Suplement 1 A-Ż. Szczecin: Uniwersytet Szczeciński, 2003.

[26] Encyklopedia Szczecina. T. Suplement 2 A-Ż. Szczecin: Uniwersytet Szczeciński, 2007.

[27] Fotyma M., Pietruch C., Nawozy i Nawozenie, Fertilizers and Fertilization. 2005, 3(8).

[28] Hemond H. F., Environmental Science Res. Rep. 14 (1994) 103- 115

[29] Hermanowicz W., Dojlido J., Dożańska W., Koziorowski B., Zerbe J., Fizyczno-chemiczne badanie wody $i$ ścieków, Arkady, Warszawa 1999.

[30] Högberg P., Jensen P., Water and Soil Pollut., 61 (1994) 361-383

[31] Kabata-Pendias A., Piotrowska M., Motowicka-Terelak T., Maliszewska-Kordybach T., Kasperczyk M., Filipek J., Zesz. Probl. Post. Nauk Roln., 276 (1983) 133-141.

[32] Kasperczyk M., Filipek J., Zesz. Probl. Post. Nauk Roln. 276 (1983) 133-141.

[33] Kowalkowski A., Monografia Świętokrzyskiego Parku Narodowego. Przyroda, Gospodarka, Kultura., Bodzentyn- Kraków 2000: 169-196.

[34] Kowalkowski A., Jóźwiak M., Kozłowski R., Zintegrowany Monitoring Środowiska Przyrodniczego. Bibl. Monitoringu Środowiska. Kielce 2001: 253-270

[35] Kölling C., Hoffmann M., Gulder H. J., Zeitschr, Pflanzenern. Bodkde, 159 (1996) 69-77.

[36] Leśniok M., Zanieczyszczenie wód opadowych w obrębie Wyżyny Śląsko Krakowskiej, Wyd. UŚl, Katowice 1996.

[37] Mazur T., Zesz. Probl. PNR, 467 (1999) 151-157.

[38] Nowak W., Draszewska-Bołzan B., Biuletyn Magnezologiczny, 6(3), (2001) 310-315.

[39] Port Szczecin. Informacja ogólne. Urząd Morski w Szczecinie. 2009

[40] Port w Szczecinie nabrzeża. Zarząd Morskich Portów Szczecin i Świnoujście SA. 2009

[41] Raben G.H., Bodenmonitoring in Sachsen. Material zum Bodenschutz. Dresden 2001, $33-57$

[42] Rehfuess K. E., Forstwiss. Centralbl, 118 (1999) 88-96.

[43] Reuss J. V., Soil acidity. Springer Verl., Berlin 1991, etc: 203-217.

[44] Reuss J. O., Johnson D. W. Eological Studies 59. Springer Verl. New York 1986, etc: $1-120$.

[45] Rost-Siebert K, Ber. Forschungszentrums Waldökosysteme/Waldsterben, Göttingen. Band, 12 (1985) 1-219.

[46] Van Miegroet H., Environmental Science Res. Rap. 14 (1994) 34-49.

[47] Warda M., Krzywiec D., Ćwintal H., Zesz. Probl. PNR, 434 (1996) 537-542.

[48] Warfvinge P., Svedrup H., Water, Air and Soil Pollution, 63 (1992) 119-143.

[49] Warfvinge P., Svedrup H., Rep. In Ecology and Environment. Engineering 5 (1995) 1-104.

[50] Zestaw Norm - Woda i ścieki. Wyd. Normalizacyjne Alfa - Wero. Warszawa 1999. 